SHS Web of Conferences 10, 00027 (2014)

DOI: $10.1051 /$ shsconf/20141000027

C Owned by the authors, published by EDP Sciences, 2014

\title{
The presentation of senior citizens in Czech media
}

\author{
A. Molinova and R. Prokopova \\ Hradec Králové University, Czech Republic
}

\begin{abstract}
Czech media do not participate on formation of the intergenerational solidarity and understanding but they might be one of the causes of intergenerational gap in the Czech Republic. Young people do not have a chance to learn anything about the positive sides in seniors' lives through the media. As Papežová says (2010, p. 57) if people get themselves acquainted with the process of aging in their youth it might help them to remove their concerns about this stage of life. In the future we should try to promote the positive portrait of seniors in Czech media and the mediation of communication between seniors and the young generation. If the media give more space to the topics concerning seniors and picture these in more positive manner, it is one of the ways how to fight with still growing intergenerational gap.
\end{abstract}

\section{Introduction}

Media influence our society further and further today. We come across their effects every day, on various places and during different activities. Whether we like it or not media influence each of us and it is not possible to avoid the impact. In our society media fulfill many important roles and they have their own specific importance in formation of opinions, attitudes and values. However their impact does not have to be always positive. For example some of their actions can have really dangerous effect as is portraying of violence, aggression and another improper behaviour as well as spending disproportionately long periods of one's free time occupying oneself with media. Media give us many topics for discussions and they determine what will be discussed more and what less. Thereby they influence relationships and what is happening in the society.

From a demographic perspective the population in the Czech Republic is inevitably growing old. "If the proportion of the population older than 65 years formed 14 per cent of inhabitants of the Czech Republic in 2005, it is estimated that this proportion will have increased about 10 per cent by 2030. The Czech Statistical Office estimates the number of people in the age of 60 and older to be 29 per cent. The situation is analogical in the most countries of the European Union. Senior citizens gradually become a very significant segment of the society" (Sedláková, 2008, www.pulib.sk). This change of the age composition of the Czech population is related to the decrease of birth-rate as well as to further extension of life expectancy. As Slowík says (2007, p. 153), even those who would not live into high age in the past do so today due to still improving medical and social care. The society should cope with the ageing population because this demographic phenomenon cannot be stopped. Nowadays, senior citizens become more often the target group of various political discussions or changes and they even attract attention of many organizations. The most of these organizations are focused on providing care, education and filling of the free time of senior citizens. Unfortunately age is still the index which emphasises primarily differences between generations rather than connecting elements.

This is an Open Access article distributed under the terms of the Creative Commons Attribution License 4.0, which permits unrestricted use, distribution, and reproduction in any medium, provided the original work is properly cited. 


\section{SHS Web of Conferences}

In our society we can often come across the term ageism meaning "set of prejudices or negative ideas related to old age and old people and manifestations of discrimination based on age" (Slowík, 2007, p. 154). Most of these manifestations are caused by insufficient or biased public awareness of old people's lives. Therefore the media are the responsible ones that should take care of public awareness and influence the public opinion. The post thus focuses on the way how seniors are portrayed in Czech media today and how this influences their position in the society.

\section{First research "the media presentation of senior citizens in selected media"}

The research was formed by 7136 posts published in selected Czech media from $1^{\text {st }}$ September 2006 to $31^{\text {st }}$ August 2007. The posts included following key words: senior, pensioner, old generation, old person and old people. Concerning the topic of seniors the vast majority of the posts were neutral 92.4 per cent, positive -4 per cent, negative -2.2 per cent and ambivalent -1.3 per cent (Graph No. 1).

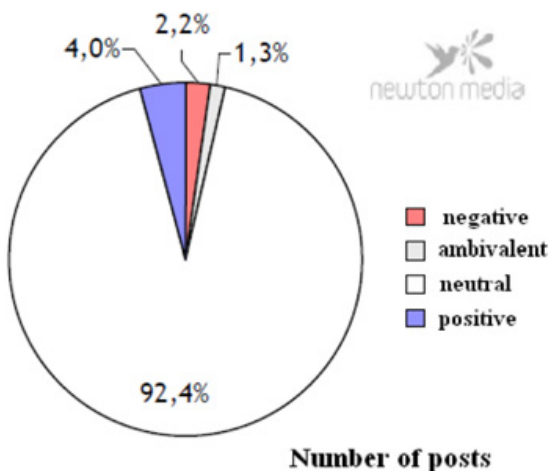

Graph 1. Posts related to senior citizens.

Social work (2140 references) was the topic that appeared most often. There were not just the posts about seniors as subjects of social care but there were posts about seniors who contribute to the charity, sew dolls for children in hospitals etc. These posts portraying seniors in active role had mostly positive spin. Altogether 56 positive posts were related to this topic. Some of these were related to taking good care of the seniors in specific retirement homes.

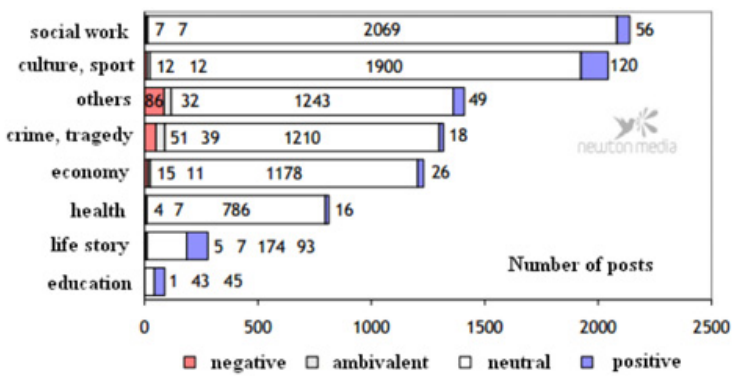

Graph 2. The most frequent topics concerning seniors.

In the most of the posts seniors were portrayed as pensioners (4631 references) or in no specific role whatsoever (2259 references). In 569 posts seniors were mentioned as citizens, often concerning 


\section{Int. Conf. SOCIETY. HEALTH. WELFARE.}

their involvement in politics. Typical were the posts about "pensioner from Vysočina" Miloš Zeman (ex-premier, current candidate for president). Media hardly ever informed about seniors as businessmen (66 references) or leader workers (38 references).

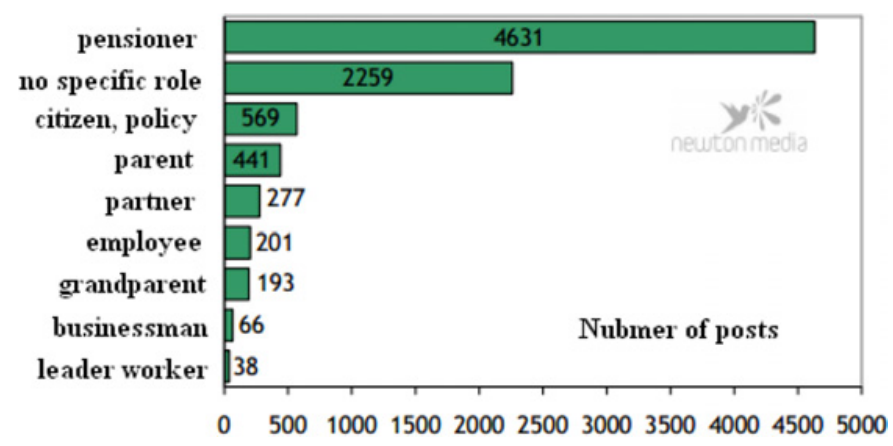

Graph 3. Senior citizens and the roles in which they are presented the most.

In one third of the posts ( 2429 references from 7136 references, i.e. 34 per cent) it was not possible to distinguish the senior's position. Retired people were more often portrayed as passive (2209 references) rather than as active (1807 references). The groups of seniors who were portrayed in active roles were formed not just by people creating some values but also by people committing violent crimes.
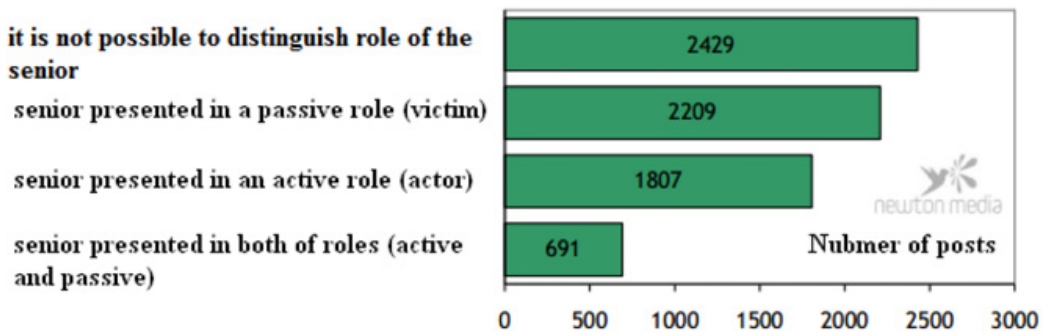

Graph 4. Senior citizens and the passive/active roles.

\section{Second research "the media analysis of portraits of senior citizens"}

The second research was published in May 2005 and its authors are Renáta Sedláková (University of West Bohemia Plzeň) and Licie Vidovićová (Masaryk University Brno). The basic set was chosen from the articles from newspapers and TV news per year 2004 (i.e. the period from $1^{\text {st }}$ January 2004 to $31^{\text {st }}$ December 2004). In the first wave of analysis the following media were monitored: daily press such as Blesk, Hospodářské noviny, Lidové noviny, Mladá fronta Dnes; audio-visual programs such as ČT 1 Události, Nova - Televizní noviny, Prima - Deník. The posts included key words: senior, senior citizens, pension, pensioner, retirement, old age, old, old man, old woman, grandmother and grandfather.

In 2004 there were recorded 261 posts with references to seniors or old age. The most posts were recorded in the Televizní noviny broadcasted on commercial television station Nova (101 posts, i.e. 39 per cent). Concerning total sum of broadcast sessions in one calendar year (about 5000 at each station) the share of references to old age is absolutely negligible. This share does not correspond to the share of elderly people in the Czech population (less than 20 per cent people over 60 years of age) and therefore it is not possible to talk about systematic coverage of this topic. 


\section{SHS Web of Conferences}

Concerning frequency of broadcast sessions in particular months the most of the posts appeared in the period with fewer events on the political scene - namely January and December. Journalists substitute lack of political events with events from other areas of social life, for example with topics related to old age.

The content of such broadcast sessions was categorized on the basis of main topic and context into 8 main scopes of interest: crime, political economy, social work, tragedy, culture, health and life story.

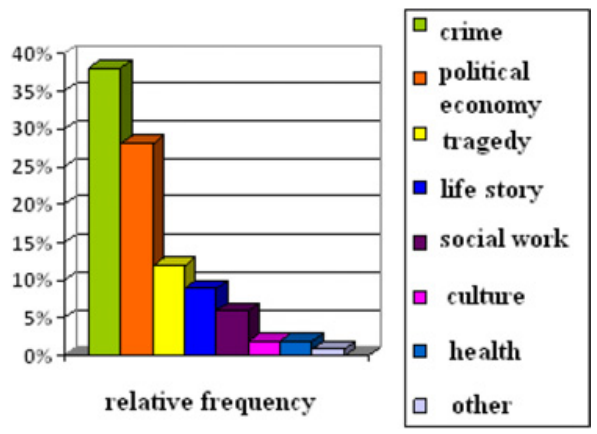

Graph 5. The thematic categories of broadcast posts.

The most frequent category was crime. 38 per cent of analysed posts belonged into this category which can be divided into 3 basic groups:

4. Seniors as crime victims

5. Seniors as offenders or being accused of crime

6. Seniors as crime witnesses.

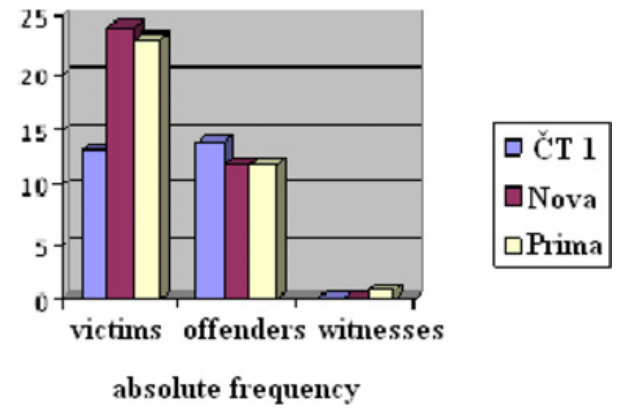

Graph 6. Absolute frequency of the posts belonging to the "crime" category.

The greatest part of the "crime" category was formed by references concerning offences whose victims were people of old age. There were primarily posts related to robbed seniors, mostly in their home environment. The thefts mentioned were frequently linked with injuries or death of the victim. The victims are more often female referred to as being helpless, lonely and credulous old women. Concerning the second category, these are mostly posts related to seniors accused of car accident. Such case can be the topic for discussions whether or not are seniors medically fit to be driving. The last category includes sometimes curious posts, for example about woman who was hiding her dead husband in the attic and she received a pension on his behalf or another post about a grower of privet for canaries who was actually cultivating marihuana instead of the privet. These posts are often of tabloid character. 


\section{Int. Conf. SOCIETY. HEALTH. WELFARE.}

Many other researches are focused on the topic of seniors and their presentation in media in the Czech Republic. However these mostly show similar results namely that media give little space to the topics concerning seniors, they focus primarily on negatives related to the process of ageing and they do not offer the young generation the possibility to learn anything about positive sides of seniors' lives. Media do not really contribute to the improvement of the intergenerational coexistence of citizens of the Czech Republic.

\section{Conclusion}

Senior citizens do not have a simple position in the contemporary society. They have to manage to deal with more and more health problems related to the process of ageing and they have to adapt on conditions in the contemporary society. Due to the rapid development of science and technology the conditions in our society are still changing and it is very difficult to adapt to them immediately. Older generations adapt to these changes frequently with difficulties and it can be one of the causes of the arising intergenerational gap.

Earlier the older generations were the source of information and life wisdom. Whenever the young generation wanted to know something, the generation of their grandparents was the primary source. Their life experience was respected and considered as a standard in decision of the whole family. The reason might be that earlier it was customary to live in intergenerational coexistence. Today the young generation obtains all information by itself as it is very simple to access different information via internet or other media. Therefore seniors find themselves in another position than they used to be and they gradually cannot keep up with the young generation.

\section{References}

[1] Papežová, E. Je tahle země "pro starý"? [Is This Country "for Old People"] Psychologie dnes, 2010, roč. 16, č. 12, s. 55-57. ISSN 1212-9607.

[2] Sedláková, R. Obraz seniorů a stáří v českých médiích aneb přispívají mediální obsahy k vytváření věkově inkluzivní společnosti? [The Image of Seniors and Aging in the Czech Media or Contribute Media to the Creation of aAge Inclusive Society]. [online]. 2008. [cit. 11. 9. 2012]. Př́stup z: http://www.pulib.sk/elpub2/FF/Bocak1/pdf_doc/sedlakova.pdf.

[3] Slowík, J. Speciální pedagogika. [Special Needs Education]. 1. vyd. Praha : Grada, 2007. $160 \mathrm{~s}$. ISBN 978-80-247-1733-3.

[4] Mediální prezentace seniorů ve vybraných médiích [ Media Presentation of Senior Citizens in Chosen Media]. [online]. 2007. [cit. 17. 9. 2012]. Př́stup z: http://www.insoma.cz/1_7.pdf. 